\title{
Rectal Prolapse
}

\author{
Scott D. Goldstein, M.D. ${ }^{1}$ and Pinckney J. Maxwell IV, M.D. ${ }^{1}$
}

\begin{abstract}
Rectal prolapse is a condition that usually requires surgical intervention to correct. Abdominal and perineal approaches are well described in the literature. Abdominal approaches have traditionally been reserved for young healthy patients, but this has been challenged by perineal approaches with excellent outcomes. Laparoscopic techniques have been shown to be effective and equivalent to traditional laparotomy techniques.
\end{abstract}

KEYWORDS: Rectal prolapse, procidentia, perineal proctectomy, Delorme procedure, Altemeier procedure

Objectives: On completion of this article, the reader should be able to summarize the various operative approaches to rectal prolapse, and offer the most appropriate surgical options for selected patients.

Rectal prolapse is the complete protrusion of the rectum through the anal canal. Rectal bleeding and a mucoid discharge are frequent symptoms. Incontinence is frequently associated with this condition as a result of either an underlying weakened sphincter, which allows the prolapse to occur, or secondarily to chronic straining and injury to the sphincter complex due to the chronic rectal prolapse.

Rectal prolapse is most frequently seen in elderly multiparous women. Other risk factors include connective tissue and psychiatric disorders as well as obesity. ${ }^{1-3}$

\section{ETIOLOGY}

The exact cause and mechanism of rectal prolapse is not completely understood. Numerous possibilities have been proposed. Rectal prolapse may be seen in childhood suggesting a congenital defect in the pelvic connective tissue or sphincter musculature. ${ }^{4}$ Pregnancy, obesity, perineal injury, chronic constipation, or other conditions resulting in increased intra-abdominal pressure are associated with rectal prolapse. Anatomic variations, such as a deep cul-de-sac of Douglas and redundant sigmoid colon, are frequently associated with the condition and may be causal.

\section{CLINICAL FEATURES}

The chief clinical feature of rectal prolapse is a protruding mass following defecation (see Fig. 1). At times, the prolapse may occur spontaneously upon standing or coughing. Rectal bleeding may be noted following bowel activity. Rectal prolapse frequently is accompanied by a mucoid discharge. A hemorrhoidal prolapse may be associated with similar symptoms and must be distinguished from a rectal prolapse by a careful physical examination.

A rectal prolapse reveals circular mucosal folds. It is generally not tender to palpation. A hemorrhoidal prolapse is a more radially appearing prolapse (see Fig. 2). The anal orifice may be patulous and a large protruding red mass is seen with a rectal prolapse.
${ }^{1}$ Division of Colon and Rectal Surgery, Department of Surgery, Jefferson Medical College of Thomas Jefferson University, Philadelphia, Pennsylvania.

Address for correspondence and reprint requests: Scott D. Goldstein, M.D., Division of Colon and Rectal Surgery, Department of Surgery, Jefferson Medical College of Thomas Jefferson University, 1100 Walnut St., \#500, Philadelphia, PA 19107 (e-mail: scott.goldstein@jefferson.edu).

Anorectal Disease; Guest Editor, Gerald A. Isenberg, M.D.

Clin Colon Rectal Surg 2011;24:39-45. Copyright (C) 2011 by Thieme Medical Publishers, Inc., 333 Seventh Avenue, New York, NY 10001, USA. Tel: +1(212) 584-4662.

DOI: http://dx.doi.org/10.1055/s-0031-1272822.

ISSN 1531-0043. 


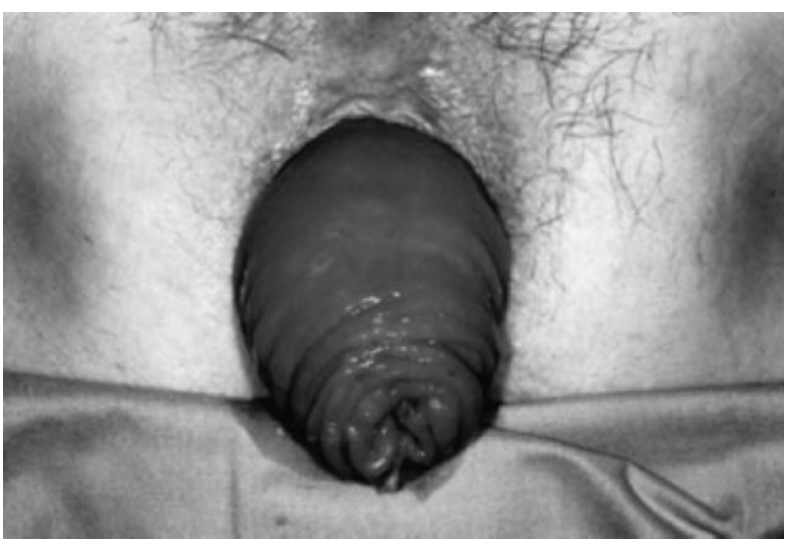

Figure 1 Rectal prolapse.

Frequently, the prolapse will be in a reduced state when the patient is initially examined. Placing the patient on a commode and asking them to strain will usually elicit the prolapse.

Incontinence frequently accompanies rectal prolapse. ${ }^{5}$ Usually, there is a long history of constipation, which precedes the prolapse by many years. It is possible that weakening of the pelvic musculature as a result of chronic defecatory straining initiates the prolapse. Baseline manometric physiologic testing to establish the state of the sphincter mechanism may be helpful.

\section{COMPLICATIONS}

The most important complication of rectal prolapse is incarceration and strangulation. Most often the rectal prolapse will reduce spontaneously. The prolapse may also at a later stage require manual reduction, which with time becomes more frequent and difficult. An incarcerated rectal prolapse may be seen after a long history of prolapse or less frequently as a presenting symptom.

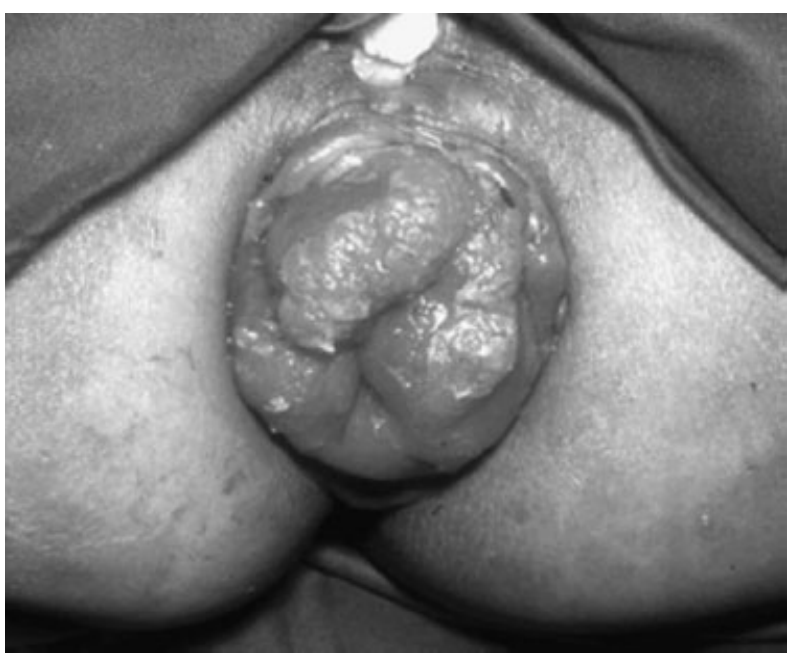

Figure 2 Hemorrhoidal prolapse.
The treatment of an incarcerated viable prolapse is to place the patient in the head-down position, applying cold compresses to the protruding mass. Injection of the anal sphincter with local anesthesia may also be helpful. After the swelling is diminished, an attempt at manual reduction is performed. If reduction is not successful or if the prolapse is strangulated, urgent operative therapy is required. A perineal approach is most appropriate. A gangrenous prolapse should always be approached by a perineal technique to avoid soiling of the peritoneal cavity by necrotic tissue. ${ }^{6}$

\section{TREATMENT}

The operative approach to rectal prolapse is controversial. Numerous factors must be considered, such as the patient's age, comorbidities, gender, and importantly, preoperative constipation. Abdominal and perineal operations are the main surgical choices.

\section{Abdominal Approaches}

The main abdominal operations performed in the United States involve suture rectopexy alone or in conjunction with a sigmoid resection. Rectal fixation utilizing synthetic materials has all but been abandoned as a result of associated complications such as infection, bowel erosion, and obstruction. ${ }^{7-9}$

The abdominal approach to repair a rectal prolapse involves mobilization of the rectum from the sacrum to the level of the anorectal junction posteriorly. After a complete rectal mobilization is performed, a posterior rectopexy is performed by direct suture fixation to the upper sacrum. Care must be taken to assure that the rectum has been completely mobilized. Failure to straighten the rectum completely could result in an immediate failure due to continued prolapse of the rectal segment distal to that, which has been "pexed" to the sacrum. Recurrence rates in the order of 0 to $9 \%$ are reported (see Table 1).

A sigmoid resection may be added to the rectopexy as reported by Frykman et al (see Fig. 3$).{ }^{10}$ Patients with a significant history of constipation coupled with a redundant sigmoid colon appear to be benefited by the addition of resectional therapy. Careful preoperative questions regarding bowel activity are imperative. At times, transit studies are a useful adjunct.

In the rectopexy with resection technique, the sigmoid colon is mobilized and a standard resection is performed utilizing a stapled or hand-sewn anastomosis. The descending colon is not mobilized. This should support the anastomosis and prevent recurrent prolapse. By removing the redundant sigmoid colon, constipation should be improved resulting in less straining, which should also help prevent recurrent prolapse. $^{7,11-14}$ 
Table 1 Results of Suture Rectopexy for Rectal Prolapse

\begin{tabular}{lllll}
\hline Source & N & Recurrence (\%) & Follow-Up (yr) & Mortality (\%) \\
\hline Carter, 198350 & 32 & 3 & 12 & 0 \\
Blatchford et al, 198951 & 42 & 2 & 2.3 & 0 \\
Novell et al, 1994 & 32 & 3 & 3.9 & 0 \\
Graf et al, 199652 & 53 & 9 & 8 & 0 \\
Khanna et al, 1996 & 65 & 0 & 5.4 & 0 \\
Briel et al, $1997^{54}$ & 24 & 0 & 5.6 & 0 \\
\hline
\end{tabular}

Rectopexy combined with anterior sigmoid resection is currently the most popular operation in the United States for rectal prolapse. Recurrence rates in the order of 0 to $9 \%$ are expected (see Table 2).

\section{Laparoscopy}

The first laparoscopic rectopexy was reported in $1993 .{ }^{15}$ Surgeons are becoming more familiar with laparoscopic rectal surgery in general, and there is no reason that this technique could not apply to rectopexy or rectopexy with sigmoid resection.

Two randomized reports compared open versus laparoscopic procedures utilizing mesh rectopexy. ${ }^{16,17}$ Both studies confirmed no difference in recurrence rates. The laparoscopic group did show less morbidity and a shorter period of hospitalization.

Ashari et $\mathrm{al}^{18}$ reported a recurrence rate of $2.5 \%$ in 117 patients treated by laparoscopic rectopexy over a 10 -year period with a low morbidity rate of $9 \%$ and a $0.8 \%$ mortality rate. Kariv et $\mathrm{al}^{19}$ reported the Cleveland Clinic experience with the laparoscopic approach. This was a case-match series comprising 111 laparoscopic with 86 open procedures. Hospital stay was reduced in the laparoscopic group (3.9 vs 6 days). The recurrence rate was $9.7 \%$ in the laparoscopic group compared with 4.7 in the open group. The difference is not statistically significant.

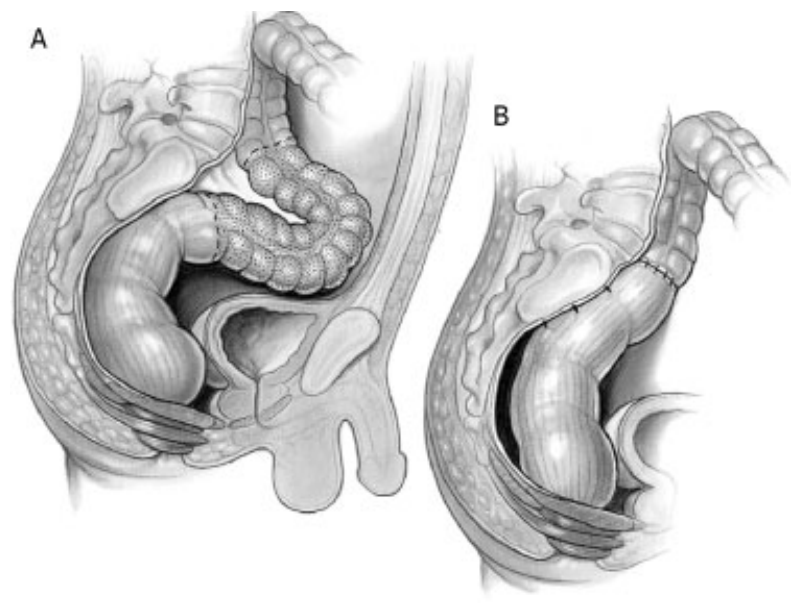

Figure 3 Sigmoid resection and rectopexy.

\section{Perineal Approaches}

Historically, the perineal approaches to rectal procidentia have higher recurrence rates, and as such have been reserved for more frail, elderly, and high-risk patients. The decreased perioperative morbidity balances the increased recurrence rate. However, recurrence rates comparable to abdominal approaches have been described with the perineal rectosigmoidectomy with levatorplasty. ${ }^{20-23}$ Importantly, perineal approaches avoid the extensive pelvic dissections required for abdominal procedures. This avoids the potential for nerve injury associated with erectile dysfunction in young men, as well as the potential for fecundity in young women. The three most commonly performed procedures are the perineal rectosigmoidectomy (Altemeier procedure), the perineal rectosigmoidectomy with levatorplasty, and the Delorme procedure.

\section{Perineal Rectosigmoidectomy}

Resection of the rectum via the perineum was first described by Mikulicz in $1889^{24}$ and Miles in $1933 .{ }^{25}$ The perineal rectosigmoidectomy bears the name Altemeier, as popularized by Altemeier and Culbertson in $1971 .{ }^{26-28} \mathrm{~A}$ transanal approach is used to perform a full-thickness excision of the rectum and a portion of the sigmoid colon. An anastomosis is then performed utilizing interrupted absorbable sutures or a circular stapling device. Excision of the redundant anterior peritoneum forming a deep pouch of Douglas should be performed as part of the resection. Perineal rectosigmoidectomy is the procedure of choice for patients presenting with an incarcerated, gangrenous rectal prolapse. The Altemeier operation is also a good option for patients with a recurrence after another perineal procedure.

Mortality rates range from $0-5 \%$ and recurrence rates range from $0-16 \%$ (see Table 3 ). ${ }^{28-33}$ Complete mobilization is critical to the success of the procedure. Resecting too much bowel can lead to an anastomosis under tension and ligating the mesentery too far proximally can lead to ischemia. Conversely, not resecting all the redundant bowel can lead to recurrence. This procedure has been reported to yield poor functional results related to soiling, fecal urgency, and fecal incontinence 
Table 2 Results of Suture Rectopexy with Resection

\begin{tabular}{lllll}
\hline Source & N & Recurrence (\%) & Follow-Up (yr) & Mortality (\%) \\
\hline Frykman and Goldberg, $1969^{12}$ & 80 & 0 & NS & NS \\
Watts et al, $1985^{29}$ & 138 & 2 & 4 & 0 \\
Husa et al, $1988^{55}$ & 48 & 9 & 4.3 & 0 \\
Sayfan et al, $1990^{56}$ & 13 & NS & NS & 0 \\
Luukkonen et al, $1992^{57}$ & 15 & 0 & NS & 6.7 \\
McKee et al, $1992^{58}$ & 9 & 0 & 1.8 & 0 \\
Tjandra et al, $1993^{59}$ & 18 & NS & 4.2 & 0 \\
Deen et al, $1994^{31}$ & 10 & 0 & 1.4 & 0 \\
Huber et al, $1995^{60}$ & 42 & 0 & 4.5 & 0 \\
Yakut et al, $1998^{38}$ & 19 & 0 & 3.2 & 0 \\
Kim et al, $1999^{33}$ & 176 & 5 & 8.2 & NS \\
\hline
\end{tabular}

NS, not stated.

due to the loss of rectal reservoir function with a narrow colon above the anal anastomosis. ${ }^{31,34}$

\section{Perineal Rectosigmoidectomy with Levatorplasy}

The perineal rectosigmoidectomy with levatorplasty has the largest recurrence-free interval, the lowest recurrence rate, and the most salutary effects on constipation and incontinence. ${ }^{5}$ Adding the posterior levatorplasty recreates the anorectal angle, seems to improve continence, and also improves the short-term recurrence rate over the perineal rectosigmoidectomy alone. ${ }^{21}$ Of the three perineal options, namely the Delorme procedure, the perineal rectosigmoidectomy, and the perineal rectosigmoidectomy with levatorplasty, the perineal rectosigmoidectomy with levatorplasty has the longest recurrence-free interval, the lowest overall recurrence rate, and the best effects in relation to incontinence and constipation. ${ }^{5}$

\section{Delorme Procedure}

Delorme first described this procedure in $1900 .^{35}$ This procedure is well suited for patients with partial circumference or short-segment full-thickness prolapse. ${ }^{5,20}$ It is also an effective treatment for mucosal or partial thickness rectal prolapse. ${ }^{36} \mathrm{~A}$ transanal approach is used to dissect the mucosa and submucosa from the sphincter complex and the muscularis propria. The redundant musoca and submucosa is excised and reanastomosed after the muscularis propria is plicated

Mortality rates range from 0 to $4 \%$ and recurrence rates range from 4 to $38 \%,{ }^{5,21,36-44}$ listed in Table 4. Morbidity is relatively uncommon and includes hemorrhage, anastomotic dehiscence, stricture, diarrhea, and

Table 3 Results of Perineal Rectosigmoidectomy for Rectal Prolapse

\begin{tabular}{|c|c|c|c|c|c|c|c|c|}
\hline Source & $N$ & Study & Levatorplasty & $\begin{array}{l}\text { Mortality } \\
(\%)\end{array}$ & $\begin{array}{l}\text { Continence } \\
(\%)\end{array}$ & $\begin{array}{l}\text { Constipation } \\
(\%)\end{array}$ & $\begin{array}{l}\text { Recurrence } \\
(\%)\end{array}$ & $\begin{array}{l}\text { Follow-Up } \\
\text { (yr) }\end{array}$ \\
\hline Altemeier et al, $1971^{28}$ & 106 & Retrospective & No & 0 & NS & NS & $3(3)$ & 19 \\
\hline Watts et al, $1985^{29}$ & 33 & Retrospective & No & 0 & $6(+), 22(-)$ & NS & 0 & 1.9 \\
\hline Prasad et al, $1986^{22}$ & 25 & NS & Yes & 0 & $88(+)$ & NS & 0 & NS \\
\hline Williams et al, $1992^{23}$ & 56 & Retrospective & No & 0 & $46(+), 0(-)$ & NS & $6(6)$ & 1 \\
\hline Williams et al, $1992^{23}$ & 11 & Retrospective & Yes & SN & $91(+)$ & NS & 0 & 1 \\
\hline Johansen et al, $1993^{30}$ & 20 & NS & No & $1(5)$ & $21(+)$ & NS & 0 & 2.2 \\
\hline Deen et al, $1994^{31}$ & 10 & Prospective & No & 0 & 80 & NS & $1(10)$ & 1.5 \\
\hline $\begin{array}{l}\text { Ramanujam et al, } \\
\qquad 1994^{32}\end{array}$ & 72 & NS & No & 0 & $67(+)$ & NS & $4(6)$ & 10 \\
\hline Agachan et al, $1997^{21}$ & 32 & Retrospective & No & 0 & $(+)$ & NS & $4(13)$ & 2.5 \\
\hline Agachan et al, $1997^{21}$ & 21 & Retrospective & Yes & 0 & $(+)$ & NS & $1(5)$ & 2.5 \\
\hline Kim et al, $1999^{33}$ & 183 & Retrospective & No & NS & $53(+)$ & $61(+)$ & $29(16)$ & 3.9 \\
\hline Takesue et al, $1999^{20}$ & 10 & NS & Yes $(7 / 10)^{*}$ & 0 & $(+)$ & NS & 0 & 3.5 \\
\hline
\end{tabular}

* Levatorplasty performed in 7 patients with incontinence.

NS, not stated; (+), improvement; (-) worsened. 
Table 4 Results of Delorme Procedure for Rectal Prolapse

\begin{tabular}{|c|c|c|c|c|c|c|c|}
\hline Source & $N$ & Study & $\begin{array}{l}\text { Mortality } \\
(\%)\end{array}$ & $\begin{array}{l}\text { Continence } \\
\text { (\%) }\end{array}$ & $\begin{array}{l}\text { Constipation } \\
(\%)\end{array}$ & $\begin{array}{l}\text { Recurrence } \\
(\%)\end{array}$ & $\begin{array}{l}\text { Follow-Up } \\
\text { (yr) }\end{array}$ \\
\hline Oliver et al, $1994^{42}$ & 41 & Retrospective & $1(2.4)$ & $58(+)$ & NS & $8(22)$ & 3.9 \\
\hline Senapati et al, $1994^{37}$ & 32 & NS & 0 & $46(+)$ & $50(+)$ & $4(12.5)$ & 1.8 \\
\hline Tobin and Scott, $1994^{36}$ & 43 & Prospective & 0 & $50(+)$ & NA & $11(26)$ & 1.7 \\
\hline Lechaux et al, $1995^{40}$ & 85 & Retrospective & $1(1.2)$ & $45(+)$ & $100(+)$ & $11(14)$ & 2.8 \\
\hline Kling et al, $1996^{43}$ & 6 & Retrospective & 0 & $67(+)$ & $100(+)$ & $1(17)$ & 11 \\
\hline Agachan et al, $1997^{21}$ & 8 & Retrospective & 0 & $(+)$ & NS & $3(38)$ & 24 \\
\hline Pescatori et al, $1998^{39}$ & 33 & Retrospective & 0 & $(+)$ & $44(+)$ & $6(18)$ & 0.9 \\
\hline Yakut et al, $1998^{38}$ & 27 & Retrospective & 0 & NS & NS & $4(4.2)$ & 3.2 \\
\hline Lieberman et al, $2000^{44}$ & 34 & Retrospective & 0 & $32(+)$ & $88(+)$ & 0 & 3.6 \\
\hline $\begin{array}{l}\text { Watts and Thompson, } \\
2000^{41}\end{array}$ & 101 & Retrospective & $4(4)$ & $25(+)$ & $13(+)$ & $30(27)$ & 3 \\
\hline
\end{tabular}

NS, not stated; NA, not applicable; (+), improvement; (-) worsened.

urinary retention. Factors associated with poor outcomes include proximal lead point with retrosacral separation seen on defecography, fecal incontinence, chronic diarrhea, and major perineal descent ( $>9 \mathrm{~cm}$ on straining). ${ }^{45}$

\section{Anal Encirclement}

Another option for severely ill patients, with significant comorbidities or portal hypertension, is anal encirclement. First described by Thiersch in $1891,{ }^{46}$ this technique involves encircling the anal canal, thereby narrowing it. This method does not correct the prolapse, rather it provides a physical barrier preventing further prolapse. Although anal encirclement has a high recurrence rate, 33 to $44 \%,{ }^{7,11,47-49}$ it may be an option for patients at very high risk for operative interventions. Providing some palliation for the prolapse may be worth the subsequent difficulties with evacuation frequently encountered after anal encirclement procedures.

\section{SURGICAL DECISION MAKING}

The choice of operation facing the surgeon is whether to offer an abdominal (open or laparoscopic) or a perineal approach.

The perineal approach is attractive because of similar recurrence rates to abdominal procedures and easier repeatability if recurrence occurs. The perineal approach is less invasive than open approaches and is associated with shorter hospital stays. It is ideal for the elderly or patients with significant comorbidities. The perineal approach can be done under regional anesthesia. The perineal approach may also be appealing to young men with sexual dysfunction as a concern.

The abdominal approach is best suited to young healthy patients with significant constipation and sigmoid redundancy and incontinence.
A randomized controlled trial of perineal proctosigmoidectomy with pelvic floor reconstruction versus open resection rectopexy and pelvic floor reconstruction showed no difference in recurrence rates; however, incontinence was significantly improved in the resection rectopexy group. ${ }^{31}$

\section{CONCLUSION}

Rectal prolapse is a chronic disturbing condition, which affects elderly women primarily, usually with a history of chronic constipation with varying degrees of incontinence. The precise etiology is unclear and there are numerous surgical options. Therapeutic decision-making is even more challenging in the younger patient population particularly in men with sexual dysfunction as an important concern.

Perineal procedures offer the advantage of a less-invasive operation with results similar to open procedures. The perineal operations can be repeated should recurrent prolapse develop. This approach would seem most appropriate in elderly debilitated and young male patients with sexual dysfunction as an important consideration. Young women may opt for a perineal procedure when cosmesis is important. Laparoscopic operations may also result in acceptable cosmesis.

Open or laparoscopic options would appear to benefit patients with significant longstanding constipation with marked sigmoid colon redundancy. Preoperative transit studies should be utilized to define the extent of the colonic dysfunction.

The ultimate decision should be made by the patient and physician after reviewing the options, risks, and benefits of the various operative techniques, and which approach best suits the individual patient.

As surgeons become more familiar with laparoscopic approaches, we will probably see a shift in this direction. Long-term outcomes following laparoscopic 
surgery for rectal prolapse appear to equal open techniques and this may emerge as the procedure of choice in the future.

\section{REFERENCES}

1. Carley ME, Schaffer J. Urinary incontinence and pelvic organ prolapse in women with Marfan or Ehlers Danlos syndrome. Am J Obstet Gynecol 2000;182(5):1021-1023

2. Karasick S, Spettell CM. The role of parity and hysterectomy on the development of pelvic floor abnormalities revealed by defecography. AJR Am J Roentgenol 1997;169(6):15551558

3. Swift S, Woodman P, O'Boyle A, et al. Pelvic Organ Support Study (POSST): the distribution, clinical definition, and epidemiologic condition of pelvic organ support defects. Am J Obstet Gynecol 2005;192(3):795-806

4. Madden MV, Kamm MA, Nicholls RJ, Santhanam AN, Cabot R, Speakman CT. Abdominal rectopexy for complete prolapse: prospective study evaluating changes in symptoms and anorectal function. Dis Colon Rectum 1992;35(1): 48-55

5. Madiba TE, Baig MK, Wexner SD. Surgical management of rectal prolapse. Arch Surg 2005;140(1):63-73

6. Ramanujam PS, Venkatesh KS. Management of acute incarcerated rectal prolapse. Dis Colon Rectum 1992;35(12): 1154-1156

7. Kuijpers HC. Treatment of complete rectal prolapse: to narrow, to wrap, to suspend, to fix, to encircle, to plicate or to resect? World J Surg 1992;16(5):826-830

8. Gordon PH, Hoexter B. Complications of the Ripstein procedure. Dis Colon Rectum 1978;21(4):277-280

9. Novell JR, Osborne MJ, Winslet MC, Lewis AAM. Prospective randomized trial of Ivalon sponge versus sutured rectopexy for full-thickness rectal prolapse. Br J Surg 1994; 81(6):904-906

10. Frykman HM. Abdominal proctopexy and primary sigmoid resection for rectal procidentia. Am J Surg 1955;90(5): 780-789

11. Jacobs LK, Lin YJ, Orkin BA. The best operation for rectal prolapse. Surg Clin North Am 1997;77(1):49-70

12. Frykman HM, Goldberg SM. The surgical treatment of rectal procidentia. Surg Gynecol Obstet 1969;129(6):12251230

13. Solla JA, Rothenberger DA, Goldberg SM. Colonic resection in the treatment of complete rectal prolapse. Neth J Surg 1989;41(6):132-135

14. Stevenson AR, Stitz RW, Lumley JW. Laparoscopic-assisted resection-rectopexy for rectal prolapse: early and medium follow-up. Dis Colon Rectum 1998;41(1):46-54

15. Munro W, Avramovic J, Roney W. Laparoscopic rectopexy. J Laparoendosc Surg 1993;3(1):55-58

16. Solomon MJ, Young CJ, Eyers AA, Roberts RA. Randomized clinical trial of laparoscopic versus open abdominal rectopexy for rectal prolapse. Br J Surg 2002;89(1):35-39

17. Boccasanta P, Rosati R, Venturi M, et al. Comparison of laparoscopic rectopexy with open technique in the treatment of complete rectal prolapse: clinical and functional results. Surg Laparosc Endosc 1998;8(6):460-465

18. Ashari LH, Lumley JW, Stevenson ARL, Stitz RW. Laparoscopically-assisted resection rectopexy for rectal pro- lapse: ten years' experience. Dis Colon Rectum 2005;48(5): 982-987

19. Kariv Y, Delaney CP, Casillas S, et al. Long term outcomes after laparoscopic and open surgery for rectal prolapse. Surg Endosc 2006;20:35-42

20. Takesue Y, Yokoyama T, Murakami Y, et al. The effectiveness of perineal rectosigmoidectomy for the treatment of rectal prolapse in elderly and high-risk patients. Surg Today 1999;29(3):290-293

21. Agachan F, Reissman P, Pfeifer J, Weiss EG, Nogueras JJ, Wexner SD. Comparison of three perineal procedures for the treatment of rectal prolapse. South Med J 1997;90(9): 925-932

22. Prasad ML, Pearl RK, Abcarian H, Orsay CP, Nelson RL. Perineal proctectomy, posterior rectopexy, and postanal levator repair for the treatment of rectal prolapse. Dis Colon Rectum 1986;29(9):547-552

23. Williams JG, Rothenberger DA, Madoff RD, Goldberg SM. Treatment of rectal prolapse in the elderly by perineal rectosigmoidectomy. Dis Colon Rectum 1992;35(9): 830-834

24. Mikulicz J. Zur operation behandlung des prolapsus recti et cold invaginati. Arch Klin Chir 1889;38:74-97

25. Miles WE. Rectosigmoidectomy as a method of treatment for procidentia recti. Proc R Soc Med 1933;26(11):14451448

26. Altemeier WA. One-stage perineal surgery for complete rectal prolapse. Hosp Pract 1972;7:102-108

27. Altemeier WA, Culbertson WR. Technique for perineal repair of rectal prolapse. Surgery 1965;58:758-764

28. Altemeier WA, Culbertson WR, Schowengerdt C, Hunt J. Nineteen years' experience with the one-stage perineal repair of rectal prolapse. Ann Surg 1971;173(6): 993-1006

29. Watts JD, Rothenberger DA, Buls JG, Goldberg SM, Nivatvongs $S$. The management of procidentia. 30 years' experience. Dis Colon Rectum 1985;28(2):96-102

30. Johansen OB, Wexner SD, Daniel N, Nogueras JJ, Jagelman DG. Perineal rectosigmoidectomy in the elderly. Dis Colon Rectum 1993;36(8):767-772

31. Deen KI, Grant E, Billingham C, Keighley MRB. Abdominal resection rectopexy with pelvic floor repair versus perineal rectosigmoidectomy and pelvic floor repair for full-thickness rectal prolapse. Br J Surg 1994;81(2): 302-304

32. Ramanujam PS, Venkatesh KS, Fietz MJ. Perineal excision of rectal procidentia in elderly high-risk patients. A ten-year experience. Dis Colon Rectum 1994;37(10):1027-1030

33. Kim D-S, Tsang CB, Wong WD, Lowry AC, Goldberg $\mathrm{SM}$, Madoff RD. Complete rectal prolapse: evolution of management and results. Dis Colon Rectum 1999;42(4):460466, discussion 466-469

34. Cutait D. Sacro-promontory fixation of the rectum for complete rectal prolapse. Proc R Soc Med 1959;52(suppl): 105

35. Delorme R. Sur le traitment des prolapses du rectum totaux pour l'excision de la muscueuse rectale ou rectocolique. Bull Mem Soc Chir Paris 1900;26:499-518

36. Tobin SA, Scott IHK. Delorme operation for rectal prolapse. Br J Surg 1994;81(11):1681-1684

37. Senapati A, Nicholls RJ, Thomson JP, Phillips RK. Results of Delorme's procedure for rectal prolapse. Dis Colon Rectum 1994;37(5):456-460 
38. Yakut M, Kaymakçioğlu N, Simek A, Tan A, Sen D. Surgical treatment of rectal prolapse. A retrospective analysis of 94 cases. Int Surg 1998;83(1):53-55

39. Pescatori M, Interisano A, Stolfi VM, Zoffoli M. Delorme's operation and sphincteroplasty for rectal prolapse and fecal incontinence. Int J Colorectal Dis 1998;13(5-6):223-227

40. Lechaux JP, Lechaux D, Perez M. Results of Delorme's procedure for rectal prolapse. Advantages of a modified technique. Dis Colon Rectum 1995;38(3):301-307

41. Watts AMI, Thompson MR. Evaluation of Delorme's procedure as a treatment for full-thickness rectal prolapse. Br J Surg 2000;87(2):218-222

42. Oliver GC, Vachon D, Eisenstat TE, Rubin RJ, Salvati EP. Delorme's procedure for complete rectal prolapse in severely debilitated patients. An analysis of 41 cases. Dis Colon Rectum 1994;37(5):461-467

43. Kling KM, Rongione AJ, Evans B, McFadden DW. The Delorme procedure: a useful operation for complicated rectal prolapse in the elderly. Am Surg 1996;62(10): $857-860$

44. Liberman H, Hughes C, Dippolito A. Evaluation and outcome of the Delorme procedure in the treatment of rectal outlet obstruction. Dis Colon Rectum 2000;43(2): 188-192

45. Sielezneff I, Malouf A, Cesari J, Brunet C, Sarles JC, Sastre B. Selection criteria for internal rectal prolapse repair by Delorme's transrectal excision. Dis Colon Rectum 1999; 42(3):367-373

46. Thiersch C. Carl Thiersch 1822-1895. Concerning prolapse of the rectum with special emphasis on the operation by Thiersch. Dis Colon Rectum 1988;31(2):154-155

47. Wassef R, Rothenberger DA, Goldberg SM. Rectal prolapse. Curr Probl Surg 1986;23(6):397-451

48. Darzi A, Henry MM, Guillou PJ, Shorvon P, Monson JR. Stapled laparoscopic rectopexy for rectal prolapse. Surg Endosc 1995;9(3):301-303

49. Dietzen CD, Pemberton JH. Perineal approaches for the treatment of complete rectal prolapse. Neth J Surg 1989;41(6): $140-144$
50. Carter AE. Rectosacral suture fixation for complete rectal prolapse in the elderly, the frail and the demented. Br J Surg 1983;70(9):522-523

51. Blatchford GJ, Perry RE, Thorson AG, Christensen MA. Rectopexy without resection for rectal prolapse. Am J Surg 1989;158(6):574-576

52. Graf W, Karlbom U, Påhlman L, Nilsson S, Ejerblad S. Functional results after abdominal suture rectopexy for rectal prolapse or intussusception. Eur J Surg 1996;162(11): 905-911

53. Khanna AK, Misra MK, Kumar K. Simplified sutured sacral rectopexy for complete rectal prolapse in adults. Eur J Surg 1996;162(2):143-146

54. Briel JW, Schouten WR, Boerma MO. Long-term results of suture rectopexy in patients with fecal incontinence associated with incomplete rectal prolapse. Dis Colon Rectum 1997; 40(10):1228-1232

55. Husa A, Sainio P, von Smitten K. Abdominal rectopexy and sigmoid resection (Frykman-Goldberg operation) for rectal prolapse. Acta Chir Scand 1988;154(3):221-224

56. Sayfan J, Pinho M, Alexander-Williams J, Keighley MRB. Sutured posterior abdominal rectopexy with sigmoidectomy compared with Marlex rectopexy for rectal prolapse. Br J Surg 1990;77(2):143-145

57. Luukkonen $\mathrm{P}$, Mikkonen $\mathrm{U}$, Järvinen $\mathrm{H}$. Abdominal rectopexy with sigmoidectomy vs. rectopexy alone for rectal prolapse: a prospective, randomized study. Int J Colorectal Dis 1992;7(4):219-222

58. McKee RF, Lauder JC, Poon FW, Aitchison MA, Finlay IG. A prospective randomized study of abdominal rectopexy with and without sigmoidectomy in rectal prolapse. Surg Gynecol Obstet 1992;174(2):145-148

59. Tjandra JJ, Fazio VW, Church JM, Milsom JW, Oakley JR, Lavery IC. Ripstein procedure is an effective treatment for rectal prolapse without constipation. Dis Colon Rectum 1993; 36(5):501-507

60. Huber FT, Stein H, Siewert JR. Functional results after treatment of rectal prolapse with rectopexy and sigmoid resection. World J Surg 1995;19(1):138-143, discussion 143 